A N N A L E S

UNIVERSITATIS MARIAE CURIE-SKŁODOWSKA

LUBLIN - POLONIA

VOL. LXXIII

SECTIO B

2018

RENATA KRUKOWSKA

ORCID ID 0000-0003-4429-0022

Wydział Nauk o Ziemi i Gospodarki Przestrzennej

Uniwersytet Marii Curie-Skłodowskiej

renata.krukowska@umcs.pl

\author{
ANDRZEJ ŚWIECA \\ ORCID ID 0000-0002-3522-4958 \\ Wydział Nauk o Ziemi i Gospodarki Przestrzennej \\ Uniwersytet Marii Curie-Skłodowskiej \\ andrzej.swieca@umcs.pl
}

\title{
Planning and implementation of urban marketing communications. The case of Lublin
}

Planowanie i wdrażanie komunikacji marketingowej miasta na przykładzie Lublina

\begin{abstract}
Abstrakt: Efektywne zarządzanie miastem wymaga wykorzystania nowoczesnych form komunikacji. Postęp, jaki dokonał się w Internecie, dostarczył ogromnych możliwości w zakresie interaktywnego komunikowania się i przekazywania informacji. Celem pracy jest przegląd i charakterystyka działań realizowanych w zakresie kreowania komunikacji marketingowej, podejmowanej w ostatnich dziecięciu latach przez miasto Lublin. W analizie wykorzystano metodę wywiadu eksperckiego oraz przeglądu literatury i dokumentów strategicznych. Opisane wyniki badań dotyczą najnowszych narzędzi stosowanych w procesie kształtowania wizerunku miasta i promowania turystyki miejskiej: aplikacji mobilnej, profili na FB i Lubelskiej Karty Turysty. Działania podejmowane w Lublinie wskazują, iż dostrzeżono już ogromną rolę mediów elektronicznych oraz społecznościowych w jego promowaniu. Przy wykorzystaniu nowoczesnych narzędzi komunikacji kreowany jest turystyczny wizerunek miasta, stanowiący kluczowy czynnik wpływający na decyzje podejmowane przez turystę, dotyczące wyboru miejsca docelowego swojego wyjazdu.
\end{abstract}

Słowa kluczowe: komunikacja marketingowa, promocja, Internet, media społecznościowe

\begin{abstract}
At present, effective city management requires the use of modern forms of communication. The progress that has been made over the Internet has provided huge opportunities for interactive communication and information transfer. The aim of the study is to review and characterize the activities carried out by the city of Lublin in creating its marketing communication over the last ten years. The basic methods used were expert interviews and quantitative and qualitative analysis of strategic documents and literature. The findings concern on tools used in the process of shaping the image of the city and promoting urban tourism: the mobile application, profiles on FB and the Lublin Tourist Card. Activities undertaken in Lublin indicate that the huge role of social media and Web 2.0 tools in the promotion of the city has already been noticed. The tourist image of the city is being created by means of modern communication tools. This image is a key factor in decisions taken by tourists regarding their travel destination.
\end{abstract}

Keywords: marketing communication, tourist promotion, Internet, social media 


\section{INTRODUCTION}

To efficiently manage a territorial unit such as a city requires its authorities to carefully consider its promotion policy. Activities of municipal units are often compared to the tasks of a company board responsible for the satisfaction of clients and positive customer experience (Krępowska 2012, p. 73). Regarded as market economy entities, cities must implement sales and promotion activities targeted at customer acquisition, and subsequently build customer loyalty (Macalik 2013, p. 147-148). This demands undertaking consistent activities aimed at tourists, including preparing and presenting a tourist offer and city symbols, as well as establishing communication methods with tourists (Glińska et al. 2009, p. 140-147).

In view of the above, marketing communication must be regarded as an important factor in the marketing activities undertaken by cities and regions (Liburd 2012). It is a form of social communication employed to meet the needs of customers by means of a range of market services (Sigala et al. 2012). It is identified with all activities related to building the idea of the company and the services it offers as well as to launching it on the market (Kuczamer-Kłopotowska 2009 , p. 548). Today, these actions require the use of modern forms of communication, since traditional channels of communication are no longer sufficient. The progress of the Internet over recent years has provided huge opportunities for interactive communication and information sharing. It has also increased the multimediality and information capacity, and the speed of data transmission and acquisition (Smul 2013, p. 90). Furthermore, the newly formed social media play an increasingly important role both in the search for travel information and promotion (Minazzi 2015).

The idea of the study is to review and characterise how the city of Lublin is creating its marketing communication over the last ten years. The aim of the analysis was to answer the question: what kind of modern forms of communication and to what extent the city of Lublin uses in urban marketing? The findings concern the latest tools used in the process of shaping the image of the city and promoting urban tourism, namely a mobile application and the Turystyczny Lublin Facebook profile, Instagram and Twitter accounts, as well as the Lublin Tourist Card.

The research for the article was carried out based on secondary and primary sources. The basic method used was the quantitative and qualitative analysis of strategic documents, studies and scientific literature. The primary sources included materials collected by the authors as part of their exploration of the Internet and case study analysis. In order to answer the research question, the authors decided to gather data by conducting expert interviews (in April 2018) 
with two City Marketing Inspectors - the staff of the Department of Tourism and the Department of Marketing of the Lublin City Office. The interviews included issues related to the city of Lublin's actions and measures used for promotion activities. Also, really important tasks and questions were connected to the role of modern technology, IT and social media in tourism marketing.

\section{THE USE OF ELECTRONIC MEDIA IN THE PROMOTION OF CITIES}

Being a constantly evolving space, a city needs to clearly define the role of tourism in its development plan. It is because a city is a product of a specific nature, an area which constitutes a sum of various objects and measures used for the development of tourism (Pawlicz 2008, p. 47). With a diverse and complex range of services offered by cities, often quite similar to each other, authorities of individual regions are compelled to seek novel tools, particularly for the purposes of promotion and image. In addition, a modern perception of promotion primarily involves the construction of a marketing strategy suitable for the given product, as well as the organisation of creative and effective promotional campaigns within the said strategy (Kruczek, Walas 2012, p. 130).

The principal instrument of managing a territorial unit is a strategy which may include all or some parts of the activities performed. A communication strategy is nowadays one of the essential elements of a proper administration. It should include developing the creation concept based on the communication strategy and designing the creation of a multimedia (Kruczek, Walas 2012, p. 129).

Contemporary marketing must be implemented comprehensively. A logo or brochures are not enough to "sell" a city and convince the public it is an attractive destination (Haysa et al. 2013). Modern promotion tools include internet travel guides, mobile communication systems (telephone, GPS), and social networking sites (Cheng, Edwards 2015). With the substantial shift in the activity of tourists and other groups into the virtual world, an effective implementation of marketing communication principles requires cities to use modern forms of communication and seize the opportunities provided by Web 2.0 tools (Kaplan, Haenlein 2010).

Activities carried out over the Internet in order to promote (communicate), sell products and services, and to build customer relationships constitute what is known as online marketing (Armstrong, Kotler 2012, p. 508). Virtualisation, or replacement (at least partially) of material resources, real processes and marketing relationship with their counterparts in a virtual environment is one of the main innovations introduced by e-marketing (Rapacz, Jaremen 2015, p. 1346-1354). A quick access to an almost unlimited amount of information 
at a relatively minimal cost is a major advantage of the Internet. The use of the Internet to build relationships and disseminate information relevant to tourists can be a key factor determining their holiday destination. Among many communication tools, the key importance is assigned to: an own website functioning as a communication tool, activities carried out by email, video services and picture-sharing applications, social networking sites and online communication (Olearnik 2016, p. 17)

Among these activities, it is Web 2.0 tools, such as social media, product review websites and blogs, that have decidedly been of the biggest importance over the last years. They have fundamentally changed the way Internet users communicate, allowing them to participate in the content posted online to a much greater extent (Pawlicz 2015, p. 177). Travellers have access to a wide range of information generated by other travellers, and the opportunity to react to the presented content, or to share their own experiences with others. This information is often considered to be more trustworthy than opinions published by industry representatives. Hence the growing importance of social networking sites in decision-making process in respect of destination and travel planning (Zajadacz 2017, p. 130).

\section{PROMOTIONAL ACTIVITIES AND THE STRATEGY FOR TOURISM DEVELOPMENT IN LUBLIN}

The analysis of source materials and opinions of experts made it possible to trace the development of tourism promotion activities and its measures in the city of Lublin's marketing.

In 2007, the city of Lublin took systematic and comprehensive steps in respect of territorial marketing in pursuit of the title of the European Capital of Culture in 2016. As a part of these activities, the brand "Lublin. City of inspiration" was created. The fundamentals of the brand were later elaborated in three large promotional campaigns, directed mainly at inhabitants of Warsaw and other big cities.

The main objective of the "Lublin. Supernatural climate" campaign (May 2008) was to increase the visibility of Lublin. The key message focused on how the history of the city blends with modernity. The campaign was conducted in the form of 150 billboards placed in Warsaw, as well as online via geotagging on such portals as onet.pl, wp.pl, Gazeta.pl and through mailing in O2.pl. The images included the frescoes located in the Holy Trinity Chapel as well as photos of contemporary young people.

"Lublin. Where great things happen" (September 2008) was the title of the campaign which used 130 billboards in Warsaw to inform the public about 
Lublin's participation in the ECOC 2016 competition and to encourage them to take part in the city's cultural events. In a symbolic manner, the posters portrayed a dialogue between the characters from the Holy Trinity Chapel and the participants of contemporary cultural events taking place in Lublin.

"Lublin. Renaissance of inspiration" (June and September 2009) was the largest campaign, related to the main promotion idea, i.e. that of the city which blends history and modernity. In the first stage, 15-second videos were prepared, showing figures from the chapel frescoes and the corresponding modern characters, such as a group of b-boys. The films were presented on digital information displays in Warsaw. They were complemented with 300 billboards placed in seven major Polish cities.

The subsequent years brought changes in the approach to the campaign. Brand campaigns were replaced with product campaigns. At present, Lublin is building its image mainly on the promotion of the Carnaval Sztukmistrzów festival. This event has become a hallmark of the city and plays a crucial role in its image-building (Pioś et al. 2014, p. 133). The promotional campaign of the event encompasses both ATL (mass marketing strategy carried out via conventional media, indoor and outdoor advertising) and BTL activities (advertising measures addressed to a particular customer).

Both experience and market studies carried out throughout the implementation of the Lublin brand were used in 2013 as the first tourism development strategy was being created. The strategy was based on the vision where "the tourist Lublin opens all the senses, enriches, and draws from the history in a manner which proves fascinating for the contemporary people. It is an open, professional and friendly city, which treads its own path, brings the East closer, and inspires". The implementation of this vision was based on the following four strategic objectives: development of tourist products, providing tourists with an anticipated standard of service and infrastructure, creation of a comprehensive system of information and promotion and developing an efficient system of management, development, cooperation and monitoring in tourism (Strategia rozwoju..., p. 4 to 8 ).

Lublin tourist products as well as the information and promotion system are to be supported by means of the state-of-the-art IT technology which accommodate the interactive tourist reception. Since tourists nowadays very often take advantage of electronic media, it is in this direction that promotional activities should be headed. 


\section{MODERN TOOLS IN LUBLIN'S MARKETING COMMUNICATIONS}

An adjustment of the tools employed to modern possibilities and trends may become an important element of the city's competitive advantage. According to a study conducted in 2015 by K. Biełuszko (2015, p. 262-266), Lublin ranked only 16 out of 18 voivodship capitals in terms of the use of electronic media in its promotion. The actions undertaken in Lublin over the last two years prove that the huge role of modern technology, IT and social media was aptly recognised and implemented in the tourism marketing tasks. On the basis of information collected during the expert interviews, it was possible to collect detailed data connected with using modern technology, IT and social media in Lublin tourism marketing.

The activities undertaken in 2016 to increase the attractiveness of Lublin, in accordance with the concept of development activities outlined in the "Tourism Development Strategy of the City of Lublin to 2025", involved the establishment of the groundwork for the Lublin Tourist Card and the Turystyczny Lublin app. These solutions were also introduced with a view to provide a professional tourist service in connection with the Great Jubilee of the 700th anniversary of its incorporation as a city, which was celebrated in 2017.

Lublin Tourist Card is a reusable proximity card, intended to facilitate the use of tourist, cultural and culinary services offered by Lublin. It provides the holder with a free access to museum objects and several tourist attractions, as well as a number of discounts in hotels and restaurants. At present, 69 entities participate in the project, including 15 museums, 23 restaurants, 8 hotels, and 23 places of interest. Lublin Tourist Card is available in a $24 \mathrm{~h}$ and $72 \mathrm{~h}$ version, at a standard and discounted tariff, and with or without a public transport ticket. The card can be purchased at an online store or at points of tourist information (https://www.lublincard.eu/pl/).

The Turystyczny Lublin mobile application, operational since 2017, is a professional and continually updated tourist guide and handbook of events in the city. In its extensive database of city attractions, tourists may also find a wide range of catering and accommodation, as well as a list of sport, recreation and entertainment facilities. The application has a built-in map with GPS location to help visitors easily reach selected objects and events. It operates both offline and online. Each place listed has a description, photos and the location pointed on the map. Modern interface offers the possibility to choose a place of a particular category, view recommended sightseeing routes, and add sites and events to a handy guide by means of the planner function (https://lublin.eu/turystyka/niezbednik-turysty/aplikacja-mobilna/). The application is available free 
of charge to download from the Internet on the three core systems, i.e. on Android, Windows Phone, and iOS (Apple). The fact that it has received the rating of 4.6 out of 5.0 in the Google Play store proves it is considered valuable by its users. At present, in the first year of operation, the application has approximately 2800 regular users.

The city of Lublin has also created profiles on the Facebook social networking portal ("Miasto Lublin", "Lublin 700", "Turystyczny Lublin"). The first one is the oldest official profile of Lublin, operating since 2011. In the course of 2017, its range increased from 56 thousand to near 66 thousand likes. The "Lublin 700" profile was devoted to the celebrations of the 700th anniversary of Lublin's incorporation in 2017. On completion of the jubilee festivities, the profile lost its validity. From 18 April 2018, it operates under a modified name, and namely "Lublin 700. Freedom inspires us". Currently, the web page is dedicated to the celebrations of Polish independence held in Lublin, with almost twenty thousand followers. "Turystyczny Lublin", the official profile of the city directed at tourists, has been operating since August 2017. It contains current information on the visiting opportunities, tourist attractions, places of interest, and events. It has approximately 2 thousand followers for the time being, but an increasing commitment of its users has been observed. In addition, the City Office is actively running an Instagram account (followed by more than ten thousand users) as well as a Twitter account (more than half thousand users).

Given the results of surveys carried out in recent years among tourists visiting Lublin, the tools used for the promotion of the city prove to be aptly selected. In the light of the analyses conducted in 2016 (Badania turystyczne... 2016, p. 37), the Internet is the main source of information about Lublin for the visitors (68\%). Traditional media rank the lowest, with television at 5\%, newspapers at $4 \%$, radio at $3 \%$, and travel agencies at $3 \%$. On the Internet, $13 \%$ of respondents start searching for information on the website of the City Office, whereas $64 \%$ on other websites. Studies of the outdoor festivals in Lublin and surveys conducted among their audiences in 2017 demonstrate that Facebook is the source of information about festivals and cultural events in Lublin most commonly used by event participants (32\%) (Kołtun (ed.) 2017, p. 15).

\section{CONCLUSIONS}

Based on expert interviews and a review of literature, documents, websites, etc., it may be noted that local authorities lean towards consistent and comprehensive promotional activities in result of cities' ever increasing competitiveness. Identity, which serves as the basis of its image, is at the heart of the marketing 
activity of a locality or a region. Cities employ integrated marketing communication more and more often. Attempts are made to manage the city image in a professional manner, also in terms of online identification. Today, these actions require the use of modern forms of communication, i.e. social media or interactive websites, since traditional channels of communication are no longer sufficient. As economic competition increases, cities can't ignore the benefits a well-thought out and articulated marketing communication can bring.

As it can be stated on the basis of the research results actions undertaken in Lublin indicate that the huge role of electronic media and social networking in the promotion of the city has already been noted. In its strategy, Lublin emphasises its Renaissance heritage, whereas in respect of typography employed, "Leonardo" is the font used in the city logo. This combination suggests that Lublin, just like da Vinci, is a city with traditions, yet modern at the same time. The tourist image of the city is being created by means of modern communication tools. This image is a key factor in decisions taken by tourists regarding their travel destination.

In conclusion, it is worth pointing out that the marketing communication function is constantly evolving. This means that in addition to traditional functions such as: information and recalling the region and its offer, integrated marketing communication should be used to educate recipients, increase their knowledge and improve their needs. An important element may also be the growing role of marketing communication in shaping the engagement of recipients, stimulating their creativity and building a partnership through a two-way exchange of information. Considering changes in consumer behavior, it should also indicate the function of building multidimensional involvement and experiences resulting from the use of the region's offer.

Authors' contribution: Renata Krukowska - 50\%, Andrzej Świeca - 50\%.

\section{REFERENCES}

Armstrong G., Kotler P., 2012: Principles of marketing. Pearson/Prentice Hall, Upper Saddle River, N.J.

Badania turystyczne Miasta Lublin 2016 (2017). Kantar Public, UM Lublin.

Biełuszko K., 2015: Media elektroniczne jako narzędzie promocji turystycznej miasta. Prace Naukowe Uniwersytetu Ekonomicznego we Wrocławiu, 349, 259-268. DOI: 10.15611/ pn.2015.379.25

Cheng M., Edwards D., 2015: Social Media in Tourism: A Visual Analytic Approach. Current Issues in Tourism, 18 (11), 1080-1087. https://doi.org/10.1080/13683500.2015.1036009 
Glińska E., Florek M., Kowalewska A., 2009: Wizerunek miasta-od koncepcji do wdrożenia. Wolters Kluwer, Warszawa, 140-147.

Haysa S., Pageb S.J., Buhalis D., 2013: Social Media as a Destination Marketing Tool: Its Use by National Tourism Organisations. Current Issues in Tourism, 16 (3), 211-239. https://doi.org/ 10.1080/13683500.2012.662215

Kaplan A.M., Haenlein M., 2010: Users of the World, Unite! The Challenges and Opportunities of Social Media. Business Horizons, 53 (1), 59-68. https://doi.org/10.1016/j.bushor.2009.09.003

Kołtun A. (red.), 2017: Wpływ lubelskich festiwali plenerowych na rozwój gospodarczy i społeczny miasta. Raport końcowy z badania. Warsztaty Kultury w Lublinie.

Krępowska U., 2012: Promocja produktu turystycznego na przyktadzie miasta Gdańska. Zarządzanie i Finanse, 2 (2), 73-89.

Kruczek Z., Walas B., 2012: Miasto jako podmiot promocji. Ocena działań promocyjnych Krakowa jako destynacji turystycznej, [w:] T. Żabińska (red.), Turystyka na obszarach miejskich. Uwarunkowania rozwoju. Narzędzia promocji. Studia Ekonomiczne. Zeszyty Naukowe Wydziałowe Uniwersytetu Ekonomicznego w Katowicach, 125-140.

Kuczamer-Kłopotowska S., 2009: Internet jako narzędzie komunikacji marketingowej. Ekonomiczne Problemy Usług, 42, 548-558.

Liburd J.J., 2012: Tourism Research 2.0. Annals of Tourism Research, 39 (2), 883-907.

Macalik J., 2013: Logotyp jako podstawowy element identyfikacji wizualnej miasta - wybrane problemy. Zeszyty Naukowe Wyższej Szkoły Bankowej we Wrocławiu, 1 (33), 147-161. https:// doi.org/10.1016/j.annals.2011.10.006

Minazzi R., 2015: Social Media Marketing in Tourism and Hospitality. Springer International Publishing Switzerland. DOI: 10.1007/978-3-319-05182-6

Olearnik J., 2016: Współczesny marketing w turystyce i jego specyfika. Ekonomiczne Problemy Turystyki, 1 (33), 9-20. DOI: 10.18276/ept.2016.1.33-01

Pawlicz A., 2008: Promocja uzupetniajaca jako element turystycznego promotion-mix miasta. Zeszyty Naukowe Uniwersytetu Szczecińskiego. Ekonomiczne Problemy Turystyki, 10, 45-54.

Pawlicz A., 2015: Wykorzystanie mediów społecznościowych jako narzędzia marketingu turystycznego przez gminy leżace na terenach parków narodowych w Polsce. Ekonomia i Środowisko, 4 (55), 176-187.

Pioś K., Skoczylas K., Brzezińska-Wójcik T., 2014: Aktualny stan i możliwości rozwoju turystyki festiwalowej w województwie lubelskim. Polish Journal of Sport and Tourism, 21, 2, 119-134.

Rapacz A., Jaremen D.E., 2015: ICT a innowacje marketingowe w przedsiębiorstwach turystycznych. Logistyka, 2, 1346-1354.

Sigala M., Christou E., Gretzel U., 2012: Social Media in Travel, Tourism and Hospitality: Theory, Practice and Cases. Ashgate Publishing Company, Burlington.

Smul P., 2013: Wykorzystanie Internetu w sprzedaży i promocji usług turystycznych. Zeszyty Naukowe Wyższej Szkoły Humanitas. Zarządzanie, 1, 88-104.

Strategia rozwoju turystyki miasta Lublin do roku 2025 (2013), (online) https://lublin.eu/turystyka/ strategia-rozwoju-turystyki/ date of access: 17.03.2018.

Zajadacz A., 2017: Media społecznościowe w procesie planowania rozwoju turystyki w skali regionalnej. Ekonomiczne Problemy Turystyki, 1 (37), 127-146. DOI: 10.18276/ept.2017.1.37-10 


\section{NETOGRAPHY}

https://lublin.eu/turystyka/niezbednik-turysty/aplikacja-mobilna/ date of access: 23.03.2018. https://www.lublincard.eu/pl/ date of access: 23.03.2018. 